\title{
Essential Skills in Postgraduate Medical Curriculum of Community Medicine
}

\author{
Jugal Kishore ${ }^{l}$, Tanu Anand ${ }^{2}$, Sneha Kumari ${ }^{l}$ \\ Vardhman Mahavir Medical College \& Safdarjung Hospital, New Delhi ${ }^{1}$, \\ North Delhi Municipal Corporation Medical College \& Hindu Rao Hospital, Delhi .
}

\begin{abstract}
Introduction: Community-based education has been considered a suitable approach for health promotion and for requisite skill development regarding primary health care. In the current perspective, public health training and research, being two important aspects require immediate attention.

Objective: To assess the skills of Postgraduate Students in the Department of Community Medicine in four Medical Colleges of Delhi.

Materials and Methods: It was a cross-sectional study conducted among 70 Postgraduate Medical Students of 4 Medical Colleges in Delhi. The data were collected through a self administered, pretested questionnaire containing items assessing socio-demographic profile and skills essential for Postgraduate Students of Community Medicine.

Results: There were $58.6 \%$ male and $29 \%$ female students. A large proportion of participants were having age range between 25-29 years. Ability 'to resolve conflict among the nurse at Primary Health Centre (PHC)', 'generate community participation', 'making thick and thin smear in case of fever',

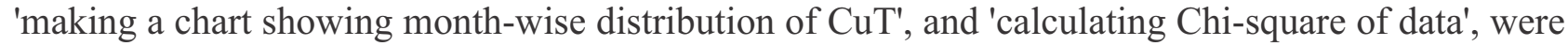
found to significantly higher in 2nd and 3rd year PG students than first year PG students $(\mathrm{p}<0.01)$. Only $27.1 \%$ of students felt that they could test water sample for microbiological aspects while only $47.1 \%$ said that they could examine an industrial worker for pre-placement examination.
\end{abstract}

Conclusions: PG students assessed themselves to possess necessary skills on communication, counselling and health education. However, many students lacked skills pertaining to occupational health and epidemiology.

Keywords: Competency in community medicine, public health, epidemiological skills, communication skills.

Correspondence : Dr. Jugal Kishore, Director Professor \& Head, Department of Community Medicine, Vardhman Mahavir Medical College \& Safdarjung Hospital, New Delhi.

GOLDEN JUBILEE COMMEMORATION AWARD LECTURE delivered during NAMSCON 2016 at the All India Institute of Medical Sciences, Raipur. 


\section{Introduction}

Based on the principles outlined at AlmaAta in 1978, there is an urgent call for revitalizing primary health care. India is not only committed to strengthening primary care but is already well aware of the means to achieving this goal (1). The National Rural Health Mission (NRHM) is a great testament to the determination of the Indian government to deliver universal primary health care and it has had impact also (2). However, there are a number of operational issues that need to be addressed to ensure that primary care is delivered effectively. And, some of the major problems in implementation and practice of primary health care relate to training and capacity building of health service providers in foreseeable future (3). It is suggested that human resources with requisite knowledge, skills, attitudes, values and responsiveness to people's health needs and health promotion are needed.

Community-based education has been considered a suitable approach for health promotion and for requisite skill development regarding primary health care $(4,5)$. In the current perspective, public health training and public health research, being two important aspects require immediate attention. The Task Force on Medical Education for the NRHM and National Health Policy 2002 have recommended increase in postgraduate seats in the discipline of Community Health/Public Health/Preventive, Social Medicine and Family Medicine (3). Thus, it is evident that in current scenario, public health specialists are the need of the hour in community health care.

The objectives and goals of Postgraduate (PG) Medical Education in Community Medicine are to produce competent specialists to manage the teaching departments in the Medical Colleges, or to manage health services and national health programs at various levels or to conduct biomedical research in the discipline of
Community Medicine (6). During training, PG are expected to acquire a substantial knowledge and necessary skills in: concepts of health and illness and their determinants, methods in community health, health services organizations, community health programs and communication and advocacy (7).

There are regional variations in the way PG training in India is imparted by various institutions. There is no well defined curriculum worked out, if at all it is there, the methods of acquiring the desired competencies are vague or not at all stated (6). Though Medical Council of India has reiterated competency-based PG training in community health care, yet, detailed structured curriculum in $P G$ training in Community Medicine is being followed in handful institutions only (8).

Considering the fact acquiring relevant public health skills during PG training is pertinent, the present study was undertaken to assess the skills of PG students in department of Community Medicine in four Medical Colleges of Delhi. This would also enable us to know the variations in PG training and evaluate whether the medical pedagogic approach is in line with objectives of such training.

\section{Materials and Methods}

\section{Study Setting and Study Participants}

It was a cross-sectional study conducted among PG Medical Students (Doctor of Medicine: MD) of 4 Medical Colleges in Delhi. Every year, 8-9 students are admitted in each of the Medical Colleges; therefore, there are around 24-27 students in each of the Department of Community Medicine of a Medical College, studying at any given time. The entire course of MD is of 3 years. The PG Students are posted for practical training in primary health care in Department of Community Medicine from first year onwards. 


\section{Description of Curriculum}

As per MCI 2000 regulations, the major components of PG Curriculum in Community Medicine constitutes:

1. Theoretical knowledge

2. Practical and clinical skills (Managerial skills)

3. Thesis skills

4. Attitudes including communication skills

5. Training in research methodology.

In order to achieve this practical training in postgraduation in Medical Colleges of Delhi is divided as follows:

The PG students are posted on rotational basis in the field practice areas of their respective Departments in different Medical Colleges for their practical training. The field areas usually cover the urban slums or resettlement colonies and rural areas include villages. The posting is of 3-6 months duration in each area. During this posting, PG students are expected to know the community, establish rapport with the community and provide essential primary care to the community. They study the community and learn to make community diagnosis. Further, they learn the implementation of national health programs at field level. They are also expected to learn management of human resources. Sometimes, their research work is also carried out in these areas.

PG students are also posted in Family Health Care program (FHCP) for undergraduates which is covered in 4th and 5th semester and epidemiology and biostatistics which are covered in 6th and 7th semester. Besides, some extra-mural visits are arranged during this posting that includes visit to a health centre, Anganwadi, Medical Records Department, Nursing College for injection techniques, MCH centre, Institute of Physically Handicapped (IPH), and Centre for Environmental and Occupational Health $(\mathrm{CEOH})$ for Biomedical Waste Management training. In addition to this, health communication classes are also held where in students learn the skills of imparting health education in a community.

PG students are also scheduled to present journal articles and take seminars on topics of public health importance. It is mandatory to do research work towards a thesis for award of the PG degree in their third year of postgraduation, they are also posted in various public health institutes and agencies like National Centre for Disease Control (NCDC), National Institute of Health and Family Welfare (NIHFW), Municipal Corporation of Delhi (MCD), New Delhi Municipal Corporation (NDMC), etc. They are also posted in the Department of Microbiology of their respective colleges for learning organisms of public health importance. Additionally, the students participate in seminars, symposia, conferences and workshops for enhancing their knowledge about the advances in public health. They are encouraged to present their research work in these fora.

The students are finally evaluated at the end of third year. There are 4 theory papers followed by 2-day practical exam that includes long case, two short cases, epidemiological and statistical exercises, spots and viva voce. Some colleges also hold microbiology practicals.

\section{Sample Size and Sampling}

There are about 8-9 PG seats for the subject in the studied Medical Colleges of Delhi. All the PG Students during the study period were included in the study. There were total of 96 PG seats in three years in the four Medical Colleges (24 in each college). Out of the 96, only 90 were filled and only 70 returned the completed questionnaires. Hence, they were included for analysis.

\section{Study Tool}

The study tool was developed after extensive review of curriculum of 
Postgraduation in Community Medicine in various institutes. The questionnaire so developed was self-administered, pre-tested and consisted of two parts. The first part contained items to gather socio-demographic information of the participants. The second part consisted of various questions to assess public health skills. To identify skills needed for PG students, emails to 50 faculty of Community Medicine were sent and their responses were listed. Questions were framed covering all skills suggested by faculty members. The skills that were assessed covered following areas: communication with the community, school health, human resource management, social mobilization, laboratory services, management of public health problem, family planning counselling, graphic representation of data, immunization, nutrition, water testing and disinfection, occupational health, health education, investigation of an epidemic, statistical tests, inventory management, evaluation of national health program, qualitative research, and surveillance.

\section{Methodology}

All the PG students of four medical colleges were contacted and the objective of study was explained to them. Informed written consent was obtained from them and then the questionnaires were given to them. The students were asked to return the filled questionnaire in 3 days. Those who failed to return were contacted again. Those students who failed to submit the filled questionnaire even after 2 remainders were excluded from the study.

\section{Ethical Considerations}

The privacy and confidentiality of data was ensured. The ethical approval of the research was obtained from the Institutional Ethics Committee (IEC) of the research institute.

\section{Statistical Analysis}

The obtained data were collected, entered and analyzed in SPSS (version 17.0). Data were expressed in terms of percentages. Differences between the proportions were observed by Chisquare test and $\mathrm{p}<0.05$ was considered as significant. Difference between independent groups for continuous variables was assessed using student $t$ test (2 groups) and One-way ANOVA(for more than 2 groups).

\section{Results}

Out of the total 70 respondents, $58.6 \%$ were male and $29 \%$ were females. Large proportion of participants was between the age of 25-29 years. More than half of the participants had their undergraduation from a private college (51.4\%). Majority of the students belonged to general category $(n=49 ; 70 \%)$. There were 29 students who were in first year of postgraduation, 18 were in 2 nd year while 23 students were studying in 3rd year. While $34.3 \%$ students had graduate mothers, half of the PG students had Fathers with professional education. Majority of students said that their mothers were housewives $(87.1 \%)$ while half had fathers engaged in semi-professional occupation (Table 1).

There were 22 competencies that were self-assessed by the students. Most of the competencies did not show year of PG wise difference. However, ability 'to resolve conflict among the nurse at Primary Health Centre (PHC)', 'generate community participation', 'making thick and thin smear in case of fever', 'making a chart showing month-wise distribution of $\mathrm{CuT}$ ', and 'calculating Chi-square of data', was found to be significantly higher in 2nd and 3rd year PG students than first year PG students $(p<0.01)$. Only $27.1 \%$ of students felt that they could test water sample for microbiological aspects while only $47.1 \%$ said that they could examine an industrial worker for pre-placement examination. Ability to evaluative DOTS or any national health program and manage inventory of health centre was possessed by $48.6 \%$ and $54.3 \%$, respectively (Table 2). 
Table 1: Socio-demographic Characteristics of Students $(n=70)$

\begin{tabular}{|c|c|}
\hline Variables & Frequency (\%) \\
\hline $\begin{array}{l}\text { Gender } \\
\text { - } \text { Male } \\
-\quad \text { Female }\end{array}$ & $\begin{array}{l}41(58.6) \\
29(41.4)\end{array}$ \\
\hline $\begin{aligned} & \text { Age } \\
&- 20-24 \text { years } \\
&- 25-29 \text { years } \\
&- 30-34 \text { years } \\
&\end{aligned}$ & $\begin{array}{l}4(5.7) \\
61(87.2) \\
5(7.1)\end{array}$ \\
\hline $\begin{array}{l}\text { Type of medical college (where MBBS done) } \\
-\quad \text { Government } \\
-\quad \text { Private }\end{array}$ & $\begin{array}{l}34(48.6) \\
36(51.4)\end{array}$ \\
\hline $\begin{aligned} & \text { Category } \\
& \text { - } \text { General } \\
& \text { - } \text { Scheduled Caste (SC) } \\
& \text { - } \text { Scheduled Tribe (ST) } \\
& \text { - } \text { Other Backward Class (OBC) }\end{aligned}$ & $\begin{array}{l}49(70.0) \\
9(12.9) \\
5(7.1) \\
7(10.0)\end{array}$ \\
\hline $\begin{array}{l}\text { Year of Postgraduation } \\
-\quad 1^{\text {st }} \text { year } \\
-\quad 2^{\text {nd }} \text { year } \\
-\quad 3^{\text {rd }} \text { year }\end{array}$ & $\begin{array}{l}29(41.4) \\
18(25.7) \\
23(32.9)\end{array}$ \\
\hline $\begin{array}{l}\text { Mother's education } \\
-\quad \text { Professional } \\
-\quad \text { Graduate } \\
-\quad 12^{\text {th }} \text { standard } \\
-\quad 10^{\text {th }} \text { standard } \\
-\quad \text { Middle school } \\
-\quad \text { Primary school } \\
-\quad \text { Illiterate }\end{array}$ & $\begin{array}{l}16(22.8) \\
24(34.3) \\
11(15.8) \\
11(15.8) \\
2(2.8) \\
1(1.4) \\
5(7.1)\end{array}$ \\
\hline $\begin{array}{c}\text { Father's education } \\
-\quad \text { Professional } \\
-\quad \text { Graduate } \\
-\quad 12^{\text {th }} \text { standard } \\
-\quad 10^{\text {th }} \text { standard } \\
-\quad \text { Primary school } \\
-\quad \text { Illiterate } \\
\end{array}$ & $\begin{array}{l}35(50) \\
26(37.1) \\
4(5.7) \\
3(4.3) \\
1(1.4) \\
1(1.4)\end{array}$ \\
\hline $\begin{array}{ll}\text { Mother's occupation } \\
- & \text { Professional } \\
- & \text { Semi-professional } \\
- & \text { Housewives } \\
\end{array}$ & $\begin{array}{l}2(2.9) \\
7(10.0) \\
61(87.1)\end{array}$ \\
\hline $\begin{aligned} & \text { Father's occupation } \\
& \text { - } \text { Professional } \\
& \text { - } \text { Semi-professional } \\
& \text { - } \text { Clerical, shop owners, etc. } \\
& \text { - } \text { Skilled worker } \\
& \text { - } \text { Unskilled worker } \\
&- \text { Unemployed }\end{aligned}$ & $\begin{array}{l}11(15.8) \\
35(50) \\
12(17.1) \\
2(2.9) \\
1(1.4) \\
9(12.9)\end{array}$ \\
\hline
\end{tabular}


Table 2: Skill Assessment of Postgraduate Students

\begin{tabular}{|c|c|c|c|c|}
\hline \multirow[t]{2}{*}{ Skill } & \multicolumn{3}{|c|}{ Year of Post graduation (n, \%) } & \multirow[t]{2}{*}{ Total } \\
\hline & $1^{\text {st }}$ Year & $2^{\text {nd }}$ Year & $3^{\text {rd }}$ Year & \\
\hline $\begin{array}{l}\text { Communicate with a senior family member at } \\
\text { home and in field to get the information about } \\
\text { socio-demography }\end{array}$ & $26(89.7)$ & $15(83.3)$ & $20(87)$ & $\begin{array}{l}61(87.1) \\
\mathrm{p}=0.82\end{array}$ \\
\hline $\begin{array}{l}\text { Plan and carrying out school health program } \\
\text { in a school }\end{array}$ & $16(55.2)$ & $11(61.1)$ & $15(65.2)$ & $\begin{array}{l}42(60) \\
p=0.76\end{array}$ \\
\hline $\begin{array}{l}\text { Resolve conflict between two nurses working } \\
\text { under you at Primary Health Centre (PHC) }\end{array}$ & $14(48.3)$ & $16(88.9)$ & $18(78.3)$ & $\begin{array}{l}48(68.6) \\
p=0.007\end{array}$ \\
\hline $\begin{array}{l}\text { Generate community participation for clean } \\
\text { surrounding of their houses }\end{array}$ & $15(51.7)$ & $15(83.3)$ & $23(100)$ & $\begin{array}{l}53(75.7) \\
\mathrm{p}<0.001\end{array}$ \\
\hline $\begin{array}{l}\text { Negotiate with local NGO's for decreasing } \\
\text { female feticide/ANC/Institutional delivery }\end{array}$ & $16(55.2)$ & $11(61.1)$ & $15(65.2)$ & $\begin{array}{l}42(60) \\
\mathrm{p}=0.76\end{array}$ \\
\hline $\begin{array}{l}\text { Make thick and thin smear at home of } \\
\text { patient with fever }\end{array}$ & $10(34.5)$ & $13(72.2)$ & $18(78.3)$ & $\begin{array}{l}41(58.6) \\
\mathrm{p}=0.003\end{array}$ \\
\hline $\begin{array}{l}\text { Categorize TB patients based on the sputum } \\
\text { exam and history at PHC }\end{array}$ & $26(89.7)$ & $17(94.4)$ & $22(95.6)$ & $\begin{array}{l}65(92.8) \\
\mathrm{p}=0.67\end{array}$ \\
\hline $\begin{array}{l}\text { Motivate a couple to use contraceptives of } \\
\text { their choice }\end{array}$ & $27(93.1)$ & $18(100)$ & $23(100)$ & $\begin{array}{l}68(97.1) \\
\mathrm{p}=0.23\end{array}$ \\
\hline $\begin{array}{l}\text { Make chart showing month-wise distribution } \\
\text { of Copper T users }\end{array}$ & $5(17.2)$ & $16(88.9)$ & $21(91.3)$ & $\begin{array}{l}42(60) \\
\mathrm{p}<0.001\end{array}$ \\
\hline $\begin{array}{l}\text { Plot weight of a }<5 \text { child on "Road to health" } \\
\text { card }\end{array}$ & $25(86.2)$ & $17(94.4)$ & $22(95.6)$ & $\begin{array}{l}64(91.4) \\
\mathrm{p}=0.42\end{array}$ \\
\hline Give BCG vaccine to an infant & $28(96.6)$ & $17(94.4)$ & $23(100)$ & $\begin{array}{l}68(97.1) \\
p=0.22\end{array}$ \\
\hline $\begin{array}{l}\text { Plan a diet for a child suffering from grade } 2 \\
\text { PEM }\end{array}$ & $17(58.6)$ & $14(77.8)$ & $19(82.6)$ & $\begin{array}{l}50(71.4) \\
\mathrm{p}=0.14\end{array}$ \\
\hline Chlorinate one bucket of water at home & $17(58.6)$ & $10(55.6)$ & $17(73.9)$ & $\begin{array}{l}44(62.9) \\
\mathrm{p}=0.40\end{array}$ \\
\hline $\begin{array}{l}\text { Examine thoroughly an industrial worker for } \\
\text { pre-placement examination }\end{array}$ & $11(37.9)$ & $9(50)$ & $13(56.5)$ & $\begin{array}{l}33(47.1) \\
\mathrm{p}=0.40\end{array}$ \\
\hline $\begin{array}{l}\text { Deliver a health talk on diarrhoea prevention } \\
\text { and control at health centre }\end{array}$ & $27(93.1)$ & $17(94.4)$ & $23(100)$ & $\begin{array}{l}67(95.7) \\
\mathrm{p}=0.45\end{array}$ \\
\hline $\begin{array}{l}\text { Investigate an epidemic of food poisoning in a } \\
\text { village/hostel }\end{array}$ & $14(48.3)$ & $12(66.7)$ & $15(65.2)$ & $\begin{array}{l}41(58.6) \\
\mathrm{p}=0.34\end{array}$ \\
\hline Calculate Chi-square value for a given data & $13(44.8)$ & $13(72.2)$ & $21(91.3)$ & $\begin{array}{l}47(67.1) \\
\mathrm{p}=0.002\end{array}$ \\
\hline $\begin{array}{l}\text { Manage the inventory/drug store at the health } \\
\text { centre }\end{array}$ & $15(51.7)$ & $7(38.9)$ & $16(69.6)$ & $\begin{array}{l}38(54.3) \\
\mathrm{p}=0.14\end{array}$ \\
\hline $\begin{array}{l}\text { Evaluate a DOTS/Any other program in your } \\
\text { district/state }\end{array}$ & $14(48.3)$ & $6(33.3)$ & $14(60.9)$ & $\begin{array}{l}34(48.6) \\
\mathrm{p}=0.22\end{array}$ \\
\hline $\begin{array}{l}\text { Hold a focus group discussion for evaluating } \\
\text { barriers in early initiation of breastfeeding }\end{array}$ & $24(82.8)$ & $16(88.9)$ & $22(95.7)$ & $\begin{array}{l}62(88.6) \\
p=0.35\end{array}$ \\
\hline $\begin{array}{l}\text { Test the water sample for micro-biological } \\
\text { aspects }\end{array}$ & $8(27.6)$ & $4(22.2)$ & $7(30.4)$ & $\begin{array}{l}19(27.1) \\
\mathrm{p}=0.84\end{array}$ \\
\hline $\begin{array}{l}\text { Carry out dengue/vector borne surveillance in } \\
\text { a village or college }\end{array}$ & $14(48.3)$ & $13(72.2)$ & $17(73.9)$ & $\begin{array}{l}44(62.9) \\
p=0.10\end{array}$ \\
\hline
\end{tabular}


Table 3: Univariate Analysis of Total Skills Scores with Socio-demographic Variables

\begin{tabular}{|c|c|c|}
\hline Variables & Score (mean \pm s.d.) & $\mathrm{p}$ value \\
\hline $\begin{array}{l}\text { Gender } \\
\begin{aligned} & \\
- & \text { Male }(n=41) \\
- & \text { Female }(n=29)\end{aligned}\end{array}$ & $\begin{array}{l}15.71 \pm 4.11 \\
17.00 \pm 3.79\end{array}$ & 0.185 \\
\hline $\begin{aligned} \text { Type of Medical College (from where MBBS done) } \\
-\quad \text { Government }(n=34) \\
-\quad \text { Private }(n=36)\end{aligned}$ & $\begin{array}{l}16.68 \pm 3.63 \\
15.83 \pm 4.44\end{array}$ & 0.383 \\
\hline $\begin{array}{cc}\text { Year of Post graduation } \\
-\quad 1^{\text {st }} \text { year }(\mathrm{n}=29) \\
-\quad 2^{\text {nd }} \text { year }(\mathrm{n}=18) \\
-\quad 3^{\text {rd }} \text { year }(\mathrm{n}=23) \\
\end{array}$ & $\begin{array}{l}15.34 \pm 4.05 \\
16.28 \pm 3.01 \\
17.35 \pm 4.49\end{array}$ & 0.203 \\
\hline $\begin{aligned} & \text { Age } \\
&- 20-24 \text { years }(\mathrm{n}=4) \\
&- 25-29 \text { years }(\mathrm{n}=61) \\
&- 30-34 \text { years }(\mathrm{n}=5) \\
&\end{aligned}$ & $\begin{array}{l}17.00 \pm 2.16 \\
16.44 \pm 3.88 \\
13.20 \pm 5.85\end{array}$ & 0.206 \\
\hline $\begin{aligned} & \text { Mother's occupation } \\
&-\quad \text { Professional \& Semi-professional }(\mathrm{n}=9) \\
& \text { - } \text { Others }(\mathrm{n}=61)\end{aligned}$ & $\begin{array}{l}20.33 \pm 2.08 \\
16.06 \pm 3.98\end{array}$ & 0.070 \\
\hline $\begin{aligned} \text { Father's occupation } \\
\quad-\quad \text { Professional \& Semi-professional }(n=44) \\
-\quad \text { Others }(n=26)\end{aligned}$ & $\begin{array}{l}16.39 \pm 3.51 \\
15.96 \pm 4.89\end{array}$ & 0.671 \\
\hline $\begin{array}{l}\text { Mother's education } \\
-\quad \text { Professional }(n=16) \\
-\quad \text { Others }(n=59)\end{array}$ & $\begin{array}{l}16.44 \pm 3.46 \\
16.19 \pm 4.18\end{array}$ & 0.829 \\
\hline 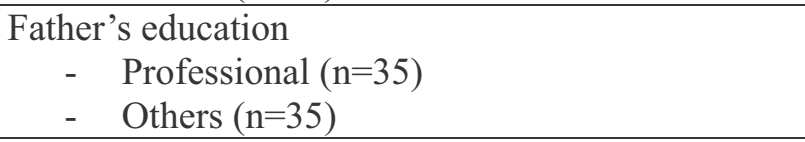 & $\begin{array}{l}16.94 \pm 3.24 \\
15.54 \pm 4.58\end{array}$ & 0.145 \\
\hline
\end{tabular}

Univariate analysis of public health skills with socio-demographic factors showed that students who are females, having graduation from Government College, being in 3rd year of PG, aged younger, mother's and father's professional education and occupation, have higher skill score than others, though the difference was not significant (Table 3).

\section{Discussion}

The medical education regulatory authority Medical Council of India (MCI) has defined essential competencies to be acquired at the end of PG education in Community Medicine. These include managerial and epidemiological skills in health care delivery system and national health programs, skills to identify community health needs, research methodology and abilities to impart training to medical and paramedical personnels (9). The present study was undertaken to assess some of these skills among the PG students of four Medical Colleges in Delhi.

Self assessment of communication and counselling skills by the PG students revealed that majority of them considered themselves to be competent to communicate with a family member of a patient and motivate eligible couple for contraceptive use. This finding is in contrast to the findings of study by Avan et al in 2005 in Pakistan (10). These high proportions give some credence to recognition by PG students of the importance of effective communication with the community and their patients. Further, interaction with people and their organization in 
urban and rural settings offers a wonderful opportunity for learning from people (9).

Epidemiology is an important part of Community Medicine and acquiring epidemiological competencies is essential for community physician (11). In the current study, only $58.6 \%$ considered themselves skilled enough to investigate an epidemic. Outbreak investigation is an opportunity to contain the epidemic and prevent future occurrence and is the best example for participatory and active learning of epidemiology. The finding highlights the need to focus on this skill among $P G$ students during their training in epidemiology. Similarly planning evaluation of national health program or carrying out surveillance of a vector borne disease are essential components of epidemiology that offer opportunity to learn multiple things.

It is a ritual to establish public health laboratory to meet the requirements of MCI. However, at many places the laboratories have not been developed. Due to lack of infrastructure in the field areas, the skills in laboratory organization for organisms of public health importance is mostly lacking among PG students as was evident in the current study as well. Even though, the students were posted in public health laboratory of MCD and Microbiology Department of their respective colleges, many students found it hard to make smears for malaria diagnosis $(41.4 \%)$ or test water sample for quality $(72.9 \%)$. This finding points to the fact even though knowledge can be gained, learning is best experienced by doing, skills need to be practiced repeatedly to develop perfection (9).

In India, the requirement of occupational health manpower is accomplished by medical graduates, community medicine specialists, and public health specialists working as industrial medical officers (12). Thus, it is evident that PG student of Community Medicine should be trained in occupational health. However, in the present study, little less than half felt that they can do pre-placement examination of an industrial worker. This is probably is due to the fact occupational health training in India is most neglected in medical curriculum.

\section{Limitations of Study}

Since our study relied on self-reporting by the PG students, this may not correspond to their performance in actual clinical and community settings. The study also could not include reporting from community people and patients themselves, which might have strengthened the results and reflected their actual behavior. Also this was a cross-sectional study involving Medical Colleges in Delhi only. The variability in PG curriculum that exists in different medical colleges and universities of the country has not been investigated in the present study.

Nevertheless, the study highlights the skills which should be possessed by a PG student of Community Medicine. In the present study, though PG students assessed themselves to possess necessary skills on communication, counseling and health education, some skills related to occupational health, public health laboratory and epidemiology need to be inculcated among them with greater stress and indicate that these needed to be included in the PG Curriculum of the MD Program in Community Medicine. Further, there is a need to reform the curriculum in terms of competencies in several areas.

\section{References}

1. Rao M, Mant D (2012). Strengthening primary healthcare in India: white paper on opportunities for partnership. $\mathrm{Br} \mathrm{Med} J$ 344: e3151.

2. Bhutta ZA, Chopra M, Axelson H, et al (2010). Countdown to 2015 decade report (2000-10): taking stock of maternal, newborn, and child survival. Lancet 375 : 2032-2044. 
3. MoHFW. Report: Task Force on Medical Education for the National Rural Health Mission. New Delhi : MoHFW: GoI.

4. The World Summit on Medical Education (1993). MedEduc 27:467-469.

5. Mash B, Villiers M (1999). Community -based training in Family Medicine a different paradigm. Med Educ 33:725729.

6. Lal S (2004). Scenario of postgraduate medical education in community medicine in India. Indian $\mathrm{J}$ Com Med 29(2):56-61.

7. Community Medicine. [Internet] (2013). Available from: http://www.oiucm.org/ community_medicinepublic_health.htm [cited on 2013 Dec 8].

8. Anonymous (2011), MCI. Vision 2015. New Delhi: Medical Council of India.
9. Lal S, Kumar R, Prinja S, Singh GPI (2011). Postgraduate teaching and evaluation in community medicine: Challenges ahead. Indian J Prev Soc Med 42(3):220-225.

10. Avan BI, Raza SA, Afridi HR (2005). Resident's perception of communication skills in postgraduate medical training programs of Pakistan. J Postgrad Med 51:85-91.

11. WHO (2011). Improving the teaching of public health at undergraduate level in medical schools-suggested guidelines. New Delhi: SEARO, WHO. Available from: http: //www.searo.who.int/entity/ primary_health_care/documents/pch_sea hsd_344.pdf.

12. Tiwari RR, Sharma A, Zodpey SP (2016). Occupational health training in India: Need for a competency-driven approach. Indian J Occup Environ Med 20:39-43. 